\title{
El professor Albert Hauf
}

\author{
RAFAEL ROCA \\ (UV) \\ Rafael.Roca@uv.es
}

Un dels professors del Departament de Filologia Catalana que més fascinava els alumnes que iniciàrem els estudis de l'antiga llicenciatura en filologia hispànica (secció valenciana) durant el curs 1989-1990 — entre els quals em comptava- era N'Albert Hauf i Valls. El prestigi acadèmic que el precedia, el cognom teutònic que assajàvem de pronunciar correctament, l'exòtic accent mallorquí, l'àvid interés pels autors medievals que transpirava... actuaren com a eficaç reclam per a nosaltres i el convertien en una autèntica rara avis acadèmica a qui admirar - i, en certa manera, imitar - per als estudiants que en aquells anys omplíem les immenses aules de l'antiga Facultat de Filologia, ben predisposats com estàvem a descobrir la cultura catalana en les seues múltiples varietats i manifestacions.

Amb tot, i per raons que no vénen al cas — com ara la meua aleshores accentuada timidesa, més pròpia d'un cartoixà que no d'un estudiant de filologia-, no vaig entrar directament en contacte amb el professor Albert Hauf fins ben avançada la carrera, fins al curs 1993-1994, quan ja feia cinqué. Fou el moment en què vaig començar a preparar una edició divulgativa de les poesies de Jordi de Sant Jordi que finalment veié la llum a l'extinta Institució Valenciana d'Estudis i Investigacions, i per al feliç desenllaç de la qual em resultà fonamental l'ajut de dos professors: Albert Hauf i Vicent Josep Escartí, als quals mai no agrairé prou la paciència i l'amabilitat amb què aclariren els meus dubtes i m'oferiren recolzament i consells — «Mira de ser sempre caut», em digué el professor Hauf durant una d'aquelles converses.

Tan sols uns mesos després, em vaig convertir en un dels privilegiats alumnes - entre els quals recorde Jaume J. Chiner Gimeno i Antoni López Quiles- que assistien als seus reduiits i captivadors cursets de doctorat, i fou així que la meua relació amb ell esdevingué més pròxima i estreta. En aquell moment, ja feia anys que el professor Hauf s'havia convertit en un referent intel-lectual per a bona part de la societat valenciana - la seua presència en les activitats i el jurat dels premis Octubre així ho confirmava-, i fou això i el contacte personal amb ell el que em portà a proposar als membres del Consell de redacció de la revista Saó — al qual feia poc més d'un any que m'havia incorporat - la possibilitat de fer-li una entrevista. La idea fou acceptada de bon grat, i en el núm. 178 de Saó, corresponent a l'octubre de 1994, aparegué publicada la transcripció de la llarga conversa — deu 
pàgines!: 25-31 i 47-49 - que vàrem mantindre al seu despatx a inicis del curs 1994-1995, i que portava per títol «Albert Hauf: la vida a través dels clàssics».

Un dels detalls que més recorde d'aquella entrevista — en què el nostre erudit afirmà coses com ara que «la cultura no té fronteres, i a l'Edat Mitjana molt menys que ara» $\mathrm{i}$ que «hi ha signes que mostren que la nostra democràcia no és tan sana com ens pensàvem»- és que, en un moment determinat, el professor Hauf asseverà que una manera eficient d'esperonar l'interés dels joves i adolescents per la cultura escrita passava, entre altres coses, per fer-los visitar els arxius: «I per què no poden fer una prova d'arxiu? Per què s'han de pensar que per fer una transcripció paleogràfica es necessiten cinc cursos d'universitat? No és veritat, això; en una hora se'ls pot ensenyar a transcriure un text medieval, i aleshores se'ls obren les portes de la recerca. Per exemple, estudiar Fuster: anar a veure els articles del Levante a la Biblioteca Universitària pot provocar una gran sensació d'importància al jove de quinze o setze anys. Veure que ell és capaç d'anar a una hemeroteca i cercar un text i fer un treballet on ha descobert un text de Fuster inèdit, per exemple».

Doncs bé, aquesta gran veritat, formulada a través d'un senzill i estimulant exemple — que, anys després, el professor Hauf em comentà que hi havia esmentat perquè ell mateix es trobava aleshores realitzant aquella recerca-, provocà les ires d'un representant de la dreta local anticatalanista, que no dubtà a escriure i publicar un article condemnatori i apocalíptic. El pecat comés pel professor Hauf? Haver unit, en una mateixa frase, dos noms propis que, en determinats cercles capitalins, provocaven urticària: el de Joan Fuster i el del diari Levante.

Tot i que els camins acadèmics que vaig emprendre durant els anys immediatament posteriors m'allunyaren progressivament de l'estudi de l'època medieval, i em conduïren vers la cultura i la literatura contemporànies —i més concretament del segle XIX - , afortunadament per a mi sempre vaig mantindre el contacte amb el professor Hauf, a qui mai no agrairé prou les paraules d'interés, afecte i encoratjament que em dedicà durant el període en què preparava la tesi doctoral, $i$ també quan iniciava la meua singladura com a professor associat del Departament de Filologia Catalana. I això sense oblidar els anys en què vaig col-laborar en els homenatges que, en 2005 i 2011, l'Acadèmia Valenciana de la Llengua dedicà als escriptors Constantí Llombart i Teodor Llorente, respectivament, i en què els meus treballs sempre varen meréixer per part seua paraules de lloança i d'ànim.

I és així que, finalment, passats més de vint anys, hem esdevingut companys de Departament, i he tingut el goig i la satisfacció de comprovar, més de prop que mai, com des de la seua actual posició de catedràtic emèrit el professor Hauf continua sent una referència d'erudició, ètica i compromís per a tots els qui ens dediquem a l'estudi i la promoció de la cultura catalana; i, molt singularment, per a les diverses fornades d'especialistes en literatura catalana medieval que s'han format al seu voltant. Unes qualitats, les que engalanen el professor Hauf, no sempre tan esteses i habituals com caldria que l'han fet mereixedor del respecte, l'agraïment i l'admiració que li dedica una part substancial de la societat valenciana. 